\title{
Short-term cropland responses to temperature extreme events during late winter
}

\author{
G. De Simon ${ }^{1}$, G. Alberti ${ }^{1}$, G. Delle Vedove ${ }^{1}$, A. Peressotti ${ }^{1}$, A. Zaldei ${ }^{2}$, and F. Miglietta ${ }^{2,3}$ \\ ${ }^{1}$ Department of Agricultural and Environmental Sciences - University of Udine, Via delle Scienze 208, 33100 Udine, Italy \\ ${ }^{2}$ CNR-IBIMET, Via Giovanni Caproni 8, 50145 Firenze, Italy \\ ${ }^{3}$ FoxLab, E. Mach Foundation, IASMA, Via E. Mach 1, 38010 San Michele all'Adige (TN), Italy
}

Correspondence to: G. De Simon (giuseppe.desimon@uniud.it)

Received: 13 March 2013 - Published in Biogeosciences Discuss.: 8 April 2013

Revised: 24 June 2013 - Accepted: 2 July 2013 - Published: 16 August 2013

\begin{abstract}
In recent years, several studies have focused on terrestrial ecosystem response to extreme events. Most of this research has been conducted in natural ecosystems, but few have considered agroecosystems. In this study, we investigated the impact of a manipulated warmer or cooler late winter/early spring on the carbon budget and final harvest of a soybean crop (Glycine max (L.) Merr.). Soil temperature was altered by manipulating soil albedo by covering the soil surface with a layer of inert silica gravel. We tested three treatments - cooling (Co), warming (W), mix (M) - and control (C). An automated system continuously measured soil heterotrophic respiration $(\mathrm{Rh})$, soil temperature profiles, and soil water content across the entire year in each plot. Phenological phases were periodically assessed and final harvest was measured in each plot. Results showed that treatments had only a transient effect on daily $\mathrm{Rh}$ rates, which did not result in a total annual carbon budget significantly different from control, even though cooling showed a significant reduction in final harvest. We also observed anticipation in emergence in both $\mathrm{W}$ and $\mathrm{M}$ treatments and a delay in emergence for Co. Moreover, plant density and growth increased in $\mathrm{W}$ and $\mathrm{M}$ and decreased in Co. In conclusion, from the results of our experiment we can assert that an increase in the frequency of both heat and cold waves is unlikely to have large effects on the overall annual carbon balance of irrigated croplands.
\end{abstract}

\section{Introduction}

Several studies have focused on the effects of gradual climatic changes (e.g. increase in mean annual temperature, increase in mean atmospheric $\mathrm{CO}_{2}$ concentration, etc.; Jentsch et al., 2007) on the carbon cycle. In particular, as soil respiration (Rs) is the second largest carbon flux in most ecosystems (Davidson et al., 2002) and can influence the overall soil carbon reservoir, there has been a growing interest in the effects of gradual climate change on this outgoing flux and in feedbacks on atmospheric $\mathrm{CO}_{2}$ concentration related to its possible increase (Cox et al., 2000; Jones et al., 2003; Knorr et al., 2005; Davidson and Janssens, 2006; Heimann and Reichstein, 2008; Mahecha et al., 2010). Estimated global Rs in 2008 amounted to $98 \pm 12 \mathrm{PgC}$, with an increasing rate of $0.1 \mathrm{Pg} \mathrm{C} \mathrm{yr}^{-1}$ between 1989 and 2008, implying a global Rs response to temperature $\left(Q_{10}\right)$ of 1.5 (Bond-Lamberty and Thomson, 2010). Recently, several papers regarding the impacts of climate extremes and climate variability on the carbon cycle have also been published (Easterling et al., 2000; Jentsch et al., 2007) following the forecasted increase in both mean climatic values and occurrence of extreme weather events (Meehl et al., 2000; Jentsch et al., 2007; Jentsch and Beierkuhnlein, 2008). In fact, such events can have an even greater influence on ecosystems and societies than gradual shifts in mean temperatures and precipitation regimes (Jentsch and Beierkuhnlein, 2008). Among all, heat waves are predicted to become more frequent, intense and longer lasting (Karl and Trenberth, 2003; Meehl and Tebaldi, 2004), especially in certain areas like central-western Europe, where the length of summer heat waves has doubled and the frequency of hot days has almost tripled in recent decades (Della Marta et al., 2007). Regarding cold waves, instead, a recent paper foresaw an increased likelihood of cold in the European region (Fereday et al., 2012).

Since the total global cropland area amounted to $1.53 \times 10^{9}$ ha at the end of the last millennium (Biradar 
et al., 2009), and agriculture was estimated to account for $10-12 \%$ of total anthropogenic greenhouse gas emissions in 2005 (Loubet et al., 2011), it is clear that studying the effects of climate change and extremes on agroecosystems is a key issue in carbon dynamics and climatic research. Here, we investigate the response of soil respiration and ecosystem productivity to soil temperature manipulation (warming and cooling) in an agroecosystem during late winter/early spring, when soils are usually ploughed and soil organic matter is more accessible for microorganisms (Dungait et al., 2012). In particular, the specific objective of this work is to assess the response of a soybean crop (Glycine max (L.) Merr.) to a manipulated warmer or colder late winter/early spring, particularly focusing on soil heterotrophic respiration $(\mathrm{Rh})$ and final harvest. Our experimental hypotheses were that warm extreme events do not affect crop carbon input $\left(\mathrm{C}_{\text {input }}\right)$, while a warmer late winter/early spring leads to an increase in $\mathrm{Rh}$ (carbon output; $\mathrm{C}_{\text {output }}$ ) and, consequently, to a detectable loss of soil carbon $\left(\mathrm{C}_{\text {budget }}\right)$. On the contrary, we hypothesized that a colder late winter/early spring leads to lower $\mathrm{C}_{\text {output }}$ and thus a higher $\mathrm{C}_{\text {budget }}$.

\section{Methods}

\subsection{Study site and experimental design}

The experiment was carried out in Beano $\left(46^{\circ} 00^{\prime} \mathrm{N} 13^{\circ} 01^{\prime} \mathrm{E}\right.$, $65 \mathrm{~m}$ a.s.1.), north-eastern Italy. Mean annual temperature at the site is $13.7^{\circ} \mathrm{C}$, and mean annual precipitation is around $1200 \mathrm{~mm}$ (2000-2007). An analysis of the occurrence of local climate extremes was performed using data for two decades (1991-2000 and 2001-2010) at a meteorological station close to the study field $(\sim 10 \mathrm{~km})$. In particular, the average and standard deviation $(\sigma)$ of the daily maximum $\left(T_{\max }\right)$ and minimum temperature $\left(T_{\min }\right)$ in the late winter/early spring period (from January to April) were calculated. Then, similarly to De Boeck et al. (2010), we considered heat waves as periods encompassing at least 7 consecutive days above $T_{\max }+\sigma$ and cold waves as periods encompassing at least 7 consecutive days below $T_{\min }-\sigma$. The mean length of extreme events was expressed as the number of days above or below temperature threshold divided by the number of events.

The location is characterized by intensive, fertilized and irrigated farming. Soil is classified as a Chromi-Endoskeletic Cambisol (FAO, 2006) with the following characteristics in the $0-30 \mathrm{~cm}$ horizon: total soil organic carbon $(\mathrm{SOC})=48.4 \pm 8.5 \mathrm{tCha}^{-1}$, total $\mathrm{N}=4.2 \pm 1.1 \mathrm{t} \mathrm{N} \mathrm{ha}^{-1}$, soil bulk density $=1.25 \pm 0.15 \mathrm{~g} \mathrm{~cm}^{-3}$, soil field capacity $=23 \% \quad v / v$, wilting point $=12 \% \quad v / v$, and $\mathrm{pH}=7.1 \pm 0.02$ (Alberti et al., 2010). In this field, irrigated maize (Zea mays L.) has been cultivated during the last $30 \mathrm{yr}$. In winter, the soil is ploughed to a depth of $0.35 \mathrm{~m}$, while in spring, soils are ploughed to $0.05 \mathrm{~m}$ in preparation for sowing.

The experiment started on 1 March 2011 and lasted $1 \mathrm{yr}$ until 28 February 2012 in order to complete the annual carbon budget. A soybean crop (Glycine max (L.) Merr.) was sown on 4 May 2011 (day of year (DOY) 124), during the effective treatment period (see below for details).

The experiment setup consisted of 12 plots (3 replicates $\times 4$ treatments): 9 plots of $5 \mathrm{~m} \times 2.5 \mathrm{~m}$ (treated) and 3 control plots of $10 \mathrm{~m} \times 10 \mathrm{~m}$ derived from a previous experiment (Alberti et al., 2010). The plots were arranged in three blocks. Soil respiration measurements were performed every $2 \mathrm{~h}$ using three closed dynamic soil respiration systems based on the measurement of the increase in $\mathrm{CO}_{2}$ concentration within an automated chamber during a fixed amount of time using a non-linear regression method (Delle Vedove et al., 2007; Alberti et al., 2010). Heterotrophic respiration (Rh) was measured using two automated chambers per plot. Soil below the chambers was isolated with a root exclusion stainless-steel cylinder opened at both ends ( $32 \mathrm{~cm}$ diameter, $40 \mathrm{~cm}$ height). The steel cylinders were placed in the field after sowing and removed after final harvest. Soil temperature profiles (four type-T thermocouples for each depth: $0,2.5,5$ and $10 \mathrm{~cm}$ depth, surface ones protected from direct solar radiation) and soil water content (Decagon EC-5; 5-10 cm depth) were also continuously monitored in each plot. All variables were measured at $0.1 \mathrm{~Hz}$ and then averaged half hourly. Air temperature, humidity (HMP45AC, Vaisala), and precipitation were measured at a nearby weather station (Alberti et al., 2010).

\subsection{Warming/cooling method}

We adopted a passive method to alter soil temperature, which consisted of changing soil surface albedo by covering it with a layer $(0.5 \mathrm{~cm}$ thickness $)$ of inert silica gravel $(95.7 \%$ $\mathrm{SiO}_{2}$; $\mathrm{pH} 7-8$ in water solution; density $2.65 \mathrm{~g} \mathrm{~cm}^{-3}$; granulometry $1.2-1.8 \mathrm{~mm}$ ). Using gravel of two different colours (black and white), we set up 4 treatments: Cooling (Co; white gravel), Warming (W; black gravel), Mix (M; 4:1 black and white gravel) and Control (C; bare soil). The main advantages of this system are the low cost and the fact that no electrical power is required, while the main disadvantage is the inability to determine, a priori, a soil temperature range. Moreover, since this method depends on incident radiation over soil, treatments were not effective at night-time, on cloudy/rainy days, or after complete crop canopy closure. However, the aim of the experiment was to test the effects of soil temperature manipulation mainly outside of the growing season (i.e. late winter/early spring).

\subsection{Phenology and ecosystem productivity}

Emergence was monitored in each plot and its trend for each treatment interpolated through a logistic function. The day 
when the first derivative of the logistic curve (i.e. emergence rate) was at a maximum was assumed to be the day of emergence for the treatment. Moreover, during the growing season, the height and phenological phases of the crop, according to Fehr et al. (1971), were periodically assessed, in order to detect if there were differences in crop development due to treatments.

Crop productivity and crop yield were assessed at final harvest by destructive sampling on 22 September 2011 (DOY 265). All plants in a $1.7 \mathrm{~m} \times 1.0 \mathrm{~m}$ subplot per plot were collected. After oven-drying at $70^{\circ} \mathrm{C}$ for $48 \mathrm{~h}$, aboveand below-ground dry biomass and dry grain yield were determined. Furthermore, on a subsample of 10 plants, root: shoot ratio and harvest index were calculated. Crop residues after harvest were estimated on a $1 \mathrm{~m}^{2}$ subplot for each plot.

Considering that we are dealing with a crop rotation, the carbon input to the ecosystem $\left(\mathrm{C}_{\text {input }}\right)$ was assumed to be equal to the sum of the crop residues of the previous crop year $\left(\mathrm{CR}_{y-1} ; 2010\right)$ and those of the studied crop year $\left(\mathrm{CR}_{y}\right.$; 2011) minus the amount of carbon respired between the harvest of the previous year and the beginning of the experiment $\left(\mathrm{Rh}_{y-1}\right.$; already monitored in control plots by the same soil respiration systems):

$\mathrm{C}_{\text {input }}=\mathrm{CR}_{y-1}+\mathrm{CR}_{y}-\mathrm{Rh}_{y-1}$.

Assuming that the carbon losses from the ecosystem ( $\left.\mathrm{C}_{\text {output }}\right)$ during the study year were equal to the cumulative heterotrophic respiration $\left(\mathrm{Rh}_{y}\right)$, the total carbon budget ( $\mathrm{C}_{\text {budget }}$ ) was calculated as follows:

$\mathrm{C}_{\text {budget }}=\mathrm{C}_{\text {input }}-\mathrm{C}_{\text {output }}=\mathrm{CR}_{y-1}+\mathrm{CR}_{y}-\mathrm{Rh}_{y-1}-\mathrm{Rh}_{y}$.

\subsection{Data analysis}

Measured soil respiration data were averaged across four periods during the day (00:00-6:00; 6:00-12:00; 12:00-18:00; 18:00-24:00 LST). Days without at least three periods of data were discarded from further analysis so as not to underor overestimate soil respiration since a complete daily trend was not available. Moreover, data for days when all three replicates per treatment were not available were also discarded. In total, $14 \%$ of days were not considered in the analysis. Missing data were then gap-filled using surface temperature according to the van't Hoff equation (Lloyd and Taylor, 1994):

$R_{\mathrm{h}}=A e^{k T}$

where $R_{\mathrm{h}}$ is soil heterotrophic respiration and $T$ is soil surface temperature (Pavelka et al., 2007). Coefficients $A$ and $k$ were derived by non-linear regression. Sensitivity of soil respiration to soil temperature $\left(Q_{10}\right)$ was then calculated as

$Q_{10}=e^{10 k}$.
Data were analyzed at the end of the year and independently for the following five periods: period I, pretreatment (DOY 60-67); period II, effective treatment period (from treatment application to complete crop canopy closure, DOY 68-158); period III, after complete crop canopy closure (from complete crop canopy closure to final harvest, DOY 159-264); period IV, after final harvest period (from final harvest to ploughing, DOY 265-326); period V, after ploughing (DOY 327-60). The slope of the cumulative soil respiration curve of each period was considered as the mean daily heterotrophic respiration rate of that period.

The effects of the various treatments on soil albedo, soil temperature, and water content were tested by repeated measures ANOVA with post hoc tests (Tukey test), while the effects of treatments on daily heterotrophic respiration rates and ecosystem productivity were tested by one-way ANOVA (post hoc Tukey test). Analyses were performed with Statistical Product and Service Solution software (SPSS ${ }^{\odot}$ IBM Corp.). All errors presented in text and graphs are standard error of the mean unless reported otherwise.

\section{Results}

\subsection{Soil temperature and soil water content}

Both maximum and minimum mean air temperatures $\left(T_{\max }\right.$, $\left.T_{\min }\right)$ and their standard deviations were larger over the period 2001-2010 in comparison to $1991-2000$ ( $T_{\max }$ increased from $12.2 \pm 5.3$ to $13.0 \pm 5.6^{\circ} \mathrm{C}, T_{\min }$ from $1.8 \pm 4.5$ to $2.8 \pm 4.6^{\circ} \mathrm{C}$ (mean \pm standard deviation)). The occurrence of heat waves and their mean length also increased, growing from 6 heat waves lasting 9 days in 1991-2000 to 9 heat waves with a duration of 14 days in 2001-2010. Cold waves also increased from 4 to 8 events per decade, however their mean length decreased from 13 to 10 days. Thus, average temperatures, their variability and the occurrence of heat and cold waves during late winter/early spring increased in the last decade, in agreement with the expected climatic trends.

All treatments significantly modified soil surface albedo in comparison to $\mathrm{C}(P<0.001$; mean albedo: Co $62.6 \%$; $\mathrm{W} 9.6 \%$; M $15.7 \%$, C $22.5 \%$ ). Thus, while there were not any significant differences in soil temperature at any depth among treatments before gravel application (DOY 60-67; $P>0.05$ ), changes in soil albedo significantly modified soil temperatures during effective treatment periods (period II; $P<0.001$; Fig. 1a). In particular, maximum soil temperature deviations from control were obtained at the soil surface and were equal to $-6.8^{\circ} \mathrm{C}$ for $\mathrm{Co}$ and $+5.7^{\circ} \mathrm{C}$ for $\mathrm{W}$ treatment, while the mean differences in soil temperature at $5 \mathrm{~cm}$ depth during period II amounted to $-3.00 \pm 0.12,+2.06 \pm 0.08$ and $+1.24 \pm 0.09^{\circ} \mathrm{C}$ for $\mathrm{Co}$, W and $\mathrm{M}$, respectively. During this period, all treatments created a quite homogeneous soil temperature alteration along the soil profile, at least up to $10 \mathrm{~cm}$ depth (data not shown). Soil temperature diurnal 


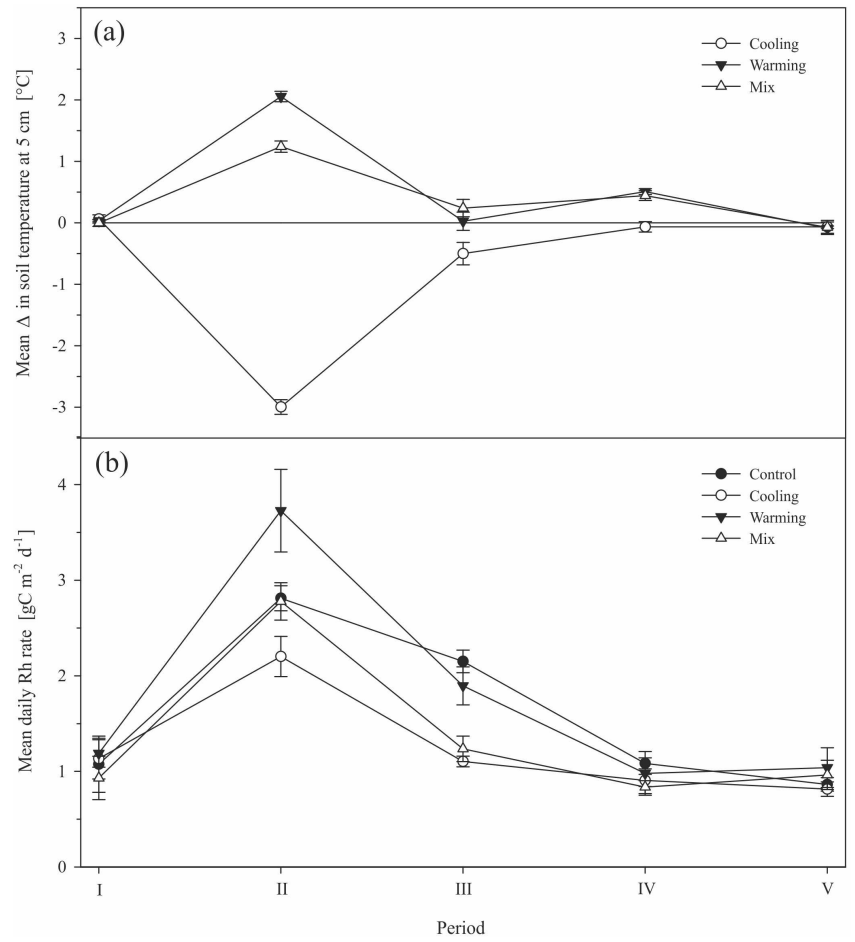

Fig. 1. Mean difference in soil temperature at $5 \mathrm{~cm}$ depth (treatment-control; a) and mean daily heterotrophic respiration rates by treatment (b) for each of the study periods considered (I to V). Period I: pretreatment (DOY 60-67); period II: effective treatment period (from treatment application to crop canopy closure, DOY 68-158); period III: after crop canopy closure (from crop canopy closure to harvest, DOY 159-264); period IV: after harvest period (from harvest to ploughing, DOY 265-326); period V: after ploughing (DOY 327-60). Vertical bars represent standard error $(n=3)$.

fluctuations were wider in $\mathrm{W}$ and narrower in Co (compared to $\mathrm{C}$ ).

After complete crop canopy closure (period III; DOY 159-264), there were no significant differences in soil temperature among treatments, except for Co, which had significantly lower soil temperatures compared with $\mathrm{C}(P=0.008)$ during the first days of this period due to a delay in crop development (see below). In the first days after final harvest (period IV; DOY 265-326), soil temperature of treatments $\mathrm{W}$ and $\mathrm{M}$ were significantly $(P<0.001)$ higher than $\mathrm{C}$ as harvest residues had not been redistributed over the soil yet, since plants were collected for laboratory measurements. Finally, after ploughing (period V; DOY 327-60), no significant differences in soil temperature were detected $(P>0.05)$.

Regarding soil moisture, during both period I and II, no significant differences were detected among treatments $(P>0.05)$. Unfortunately, just after canopy closure lightning damaged most of the soil water content sensors. Thus we were not able to assess if there was a difference in soil water content or not in the subsequent periods. However, because the crop is irrigated (a total of $310 \mathrm{~mm}$ during period II and III), soil water content was always close to field capacity $(0.25 \pm 0.04$ (mean \pm standard deviation) considering period III, IV and V; data from Time-domain reflectometers (TDR) at the weather station).

\subsection{Heterotrophic respiration}

Daily soil heterotrophic respiration ranged from 0.15 to $7.95 \mathrm{~g} \mathrm{C} \mathrm{m}^{-2} \mathrm{~d}^{-1}$ with an annual average equal to $1.77 \pm 0.07, \quad 1.27 \pm 0.05, \quad 1.96 \pm 0.23$ and $1.48 \pm 0.08 \mathrm{~g} \mathrm{C} \mathrm{m}^{-2} \mathrm{~d}^{-1}$ in $\mathrm{C}, \mathrm{Co}, \mathrm{W}$ and $\mathrm{M}$, respectively. There were no statistically significant differences in mean daily $\mathrm{Rh}$ rates before gravel application (i.e. slope of the cumulative respiration; $P>0.05$ ), while during period II $\mathrm{Rh}$ rates in Co and $\mathrm{W}$ were less than and greater than $\mathrm{C}$, respectively ( $P=0.117$ and $P=0.007$; Fig. $1 \mathrm{~b}$ ). In this period, mean daily $R$ h rates were $2.81 \pm 0.13$ in $C, 2.20 \pm 0.21$ in $\mathrm{Co}, 3.73 \pm 0.43$ in $\mathrm{W}$ and $2.78 \pm 0.20 \mathrm{~g} \mathrm{C} \mathrm{m}^{-2} \mathrm{~d}^{-1}$ in M. In period III, $\mathrm{Co}$ and $\mathrm{M}$ treatments had significantly lower daily $\mathrm{Rh}$ rates compared with $\mathrm{C}(P<0.01)$. Rh rates presented the same trend in all treatments: an increase from period I to period II followed by a decrease during periods III, IV and V. For all treatments, maximum daily $\mathrm{Rh}$ rates were found in period II.

$\mathrm{Rh}$ increased exponentially with soil temperature in all treatments, however the van't Hoff equation explained only a small part of variance $\left(\mathrm{C}: R^{2}=0.46 ; \mathrm{Co}: R^{2}=0.09\right.$; $\left.\mathrm{W}: R^{2}=0.28 ; \mathrm{M}: R^{2}=0.12 ; P<0.0001\right)$. Calculated $Q_{10}$ values were equal to $1.63 \pm 0.12,1.20 \pm 0.07,1.50 \pm 0.10$ and $1.28 \pm 0.07$ for $\mathrm{C}, \mathrm{Co}, \mathrm{W}$ and $\mathrm{M}$, respectively. $Q_{10}$ of Co was significantly lower than the $Q_{10}$ of C. Seasonal patterns of Rh were similar for all treatments; we observed an increase in spring as temperature increased, a decrease thereafter to values around $1-2 \mathrm{~g} \mathrm{C} \mathrm{m}^{-2} \mathrm{~d}^{-1}$ and a further decline in autumn after final harvest.

\subsection{Phenology and ecosystem carbon budget}

Treatments had an effect on crop development: the cooling treatment caused a lower plant density compared to $\mathrm{C}$ at all sampling dates (Fig. 2a), even if not significant $(P>0.05)$, while in $\mathrm{W}$, plant density was always higher than $\mathrm{C}$ (significantly only on 13 May, 9 days after sowing; $P=0.015$ ). However, at the end of growing season, plant density was not significantly different between any of the applied treatments and $\mathrm{C}(P>0.05)$.

Concerning emergence (first stage of Fehr-Caviness scale; Fehr et al., 1971), soil temperature manipulation led to earlier germination in comparison to $\mathrm{C}$ in both $\mathrm{W}$ and $\mathrm{M}$ treatments ( -4 days), whilst emergence was delayed by 3 days in $\mathrm{Co}$ (Fig. 2b). The survey of crop development through phenological phases (Table 1) showed that treatments $\mathrm{C}$ and $\mathrm{W}$ approximately followed the timetable for phenological phases 
Table 1. Cultural practices and phenological phases according to Fehr-Caviness scale (Fehr et al., 1971). Phenological phase abbreviations: VE= emergence; V1 = first node; V2 = second node; V $n=n$-th node; $\mathrm{R} 1=$ beginning bloom; $2=$ full bloom; R3= beginning pod; $\mathrm{R} 4=$ full pod; $\mathrm{R} 5$ = beginning seed; $\mathrm{R} 6=$ full seed.

\begin{tabular}{|c|c|c|c|c|c|}
\hline \multirow[b]{2}{*}{ Date } & \multirow[b]{2}{*}{$\begin{array}{l}\text { Days after } \\
\text { sowing }\end{array}$} & \multicolumn{4}{|c|}{ Phenological phase } \\
\hline & & Control & Cooling & Warming & Mix \\
\hline 11 May 2011 & 7 & VE & - & VE & $\mathrm{VE}$ \\
\hline 13 May 2011 & 9 & V1 & - & $\mathrm{V} 2$ & V1 \\
\hline 17 May 2011 & 13 & $\mathrm{~V} 2$ & $\mathrm{VE}$ & $\mathrm{V} 2$ & $\mathrm{~V} 2$ \\
\hline 24 May 2011 & 20 & $\mathrm{~V} 2$ & $\mathrm{~V} 1$ & V3 & $\mathrm{V} 2$ \\
\hline 30 May 2011 & 26 & V3 & $\mathrm{V} 2$ & V3 & V3 \\
\hline 9 Jun 2011 & 36 & V4 & V3 & V5 & V5 \\
\hline 14 Jun 2011 & 41 & V5 & V3 & V6 & V5 \\
\hline 20 Jun 2011 & 47 & V6 & V4 & V6 & V5 \\
\hline 30 Jun 2011 & 57 & $\mathrm{R} 1$ & V6 & $\mathrm{R} 1$ & $\mathrm{R} 1$ \\
\hline 3 Aug 2011 & 91 & R5 & $\mathrm{R} 4$ & R5 & R5 \\
\hline 9 Aug 2011 & 97 & R5 & $\mathrm{R} 4$ & R5 & $\mathrm{R} 5$ \\
\hline 17 Aug 2011 & 105 & R6 & R5 & R6 & R6 \\
\hline \multirow[t]{2}{*}{24 Aug 2011} & 112 & R6 & R6 & R6 & R6 \\
\hline & & \multicolumn{4}{|c|}{ Cultural practices } \\
\hline 19 Apr 2011 & -15 & \multicolumn{4}{|c|}{ Weed control: $5 \mathrm{kgha}^{-1}$ ammonium sulfate (N $\left.21 \%\right)+2.5 \mathrm{~kg} \mathrm{ha}^{-1}$ glyphosate $36 \%$} \\
\hline 4 May 2011 & 0 & \multicolumn{4}{|c|}{ Soybean sowing: Nikko Dekalb 1- } \\
\hline 6 May 2011 & 2 & \multicolumn{4}{|c|}{$\begin{array}{l}\text { Weed control: } 1.2 \mathrm{Lha}^{-1} \text { S-metolachlor } 86.5 \%\left(960 \mathrm{gL}^{-1}\right)+0.8 \mathrm{Lha}^{-1} \text { linuron } 36.5 \% \\
\left(425 \mathrm{~g} \mathrm{~L}^{-1}\right)\end{array}$} \\
\hline 10 May 2011 & 6 & \multicolumn{4}{|c|}{ Pest control: $2 \mathrm{~kg} \mathrm{ha}^{-1}$ metaldehyde $4.9 \%+2 \mathrm{kgha}^{-1}$ metaldehyde $3.5 \%$} \\
\hline 11 Jun 2011 & 39 & \multicolumn{4}{|c|}{$\begin{array}{l}\text { Weed control: } 2.2 \mathrm{Lha}^{-1} \text { cycloxydim } 21 \%\left(200 \mathrm{gL}^{-1}\right)+7 \mathrm{gha}^{-1} \text { thifensulfuron-methyl } \\
75 \%+1 \mathrm{Lha}^{-1} \text { imazamox }^{2} .7 \%\left(40 \mathrm{gL}^{-1}\right)\end{array}$} \\
\hline 22 Sep 2011 & 145 & \multicolumn{4}{|l|}{ Harvest } \\
\hline 23 Nov 2011 & 203 & \multicolumn{4}{|c|}{ Plowing (35 cm depth) } \\
\hline
\end{tabular}

reported by Fehr et al. (1971) in Setiyono et al. (2010). Conversely, in the cooling treatment, phase VE was delayed by 8 days, V6 by 22 days, R5 by 27 days and finally R6 by 12 days. In comparison to $\mathrm{C}$, Co presented a delay of one or more stages during the entire growing season. Nevertheless, at the end of the crop year, plants reached full maturity in all treatments.

Regarding crop height, plants were significantly smaller in Co than $\mathrm{C}$ from 30 May $(P<0.05)$, while plant height was not significantly different from $\mathrm{C}$ in $\mathrm{W}$ on any sampling date $(P>0.05)$. Finally, plant height was significantly lower in $\mathrm{M}$ compared to $\mathrm{C}$ only during the last part of the growing season (from 3 August; $P<0.05$ ).

As for the carbon budget (Fig. 3), there were no significant differences in $\mathrm{C}_{\text {input }}$ among treatments $(P=0.46)$, even if a significant reduction in harvest was recorded for Co in comparison to $\mathrm{C}$ at the end of the growing season $(-37.5 \% ; P=0.02)$, while in $\mathrm{W}$ and $\mathrm{M}$ final harvest was not significantly different from $C$ (final harvest: $4.0 \pm 0.3$ in $\mathrm{C}, 2.5 \pm 0.1$ in $\mathrm{Co}, 4.0 \pm 0.4$ in $\mathrm{W}$ and $3.4 \pm 0.1 \mathrm{tDM} \mathrm{ha}^{-1}$ in $\mathrm{M})$. Annual total $\mathrm{Rh}$ ( $\mathrm{C}_{\text {output }}$ ) and total carbon budget
$\left(\mathrm{C}_{\text {budget }}\right)$ of all treatments did not differ significantly from $\mathrm{C}(P>0.05)$.

\section{Discussion and conclusions}

The overall net effect of extreme events on the carbon balance of a cropping system is the result of the difference between carbon gains and losses. In this study we were able to enhance/decrease soil temperatures in a realistic way by modifying soil albedo, especially before complete crop canopy closure (Fig. 1a). When soil water is in ample supply, as in our irrigated system, an increase in temperature may indeed translate into increased soil carbon losses. Our results show that heterotrophic respiration was stimulated by soil warming, possibly leading to a rapid depletion of the most labile soil carbon stock. As a consequence, the enhanced respiration pulse was followed by reduced respiration rates when the substrate, and not the temperature, subsequently became limiting (Fig. 4). It is also interesting to consider that a higher soil temperature promoted initial growth of the crop by affecting, to some extent, its phenology; crop emergence was brought forward by 4 days in response to soil warming, in 


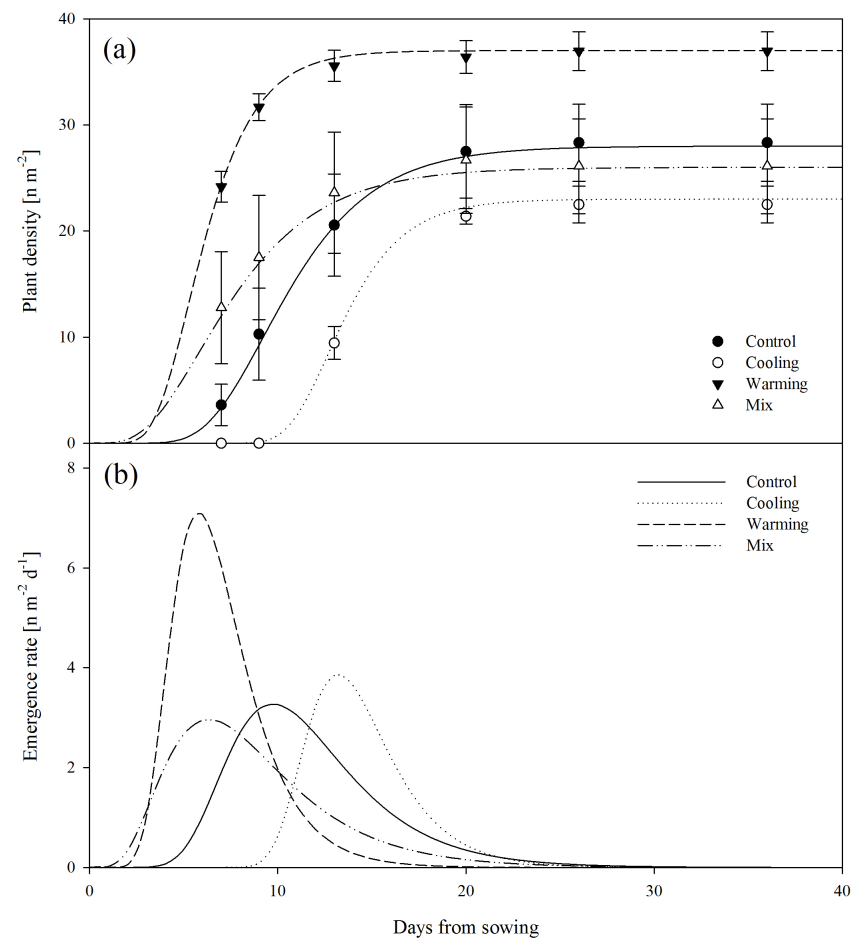

Fig. 2. Crop development: plant density (a) and emergence rate (b). Vertical bars represent the standard error $(n=3)$.

agreement with Menzel et al. (2006), who predicted an earlier onset of germination of 2.5 days ${ }^{\circ} \mathrm{C}^{-1}$ in a future global warming scenario. However, this did not translate into an earlier flowering date and, more importantly, into a larger biomass and crop yield at the end of the growing season, an effect that was also observed in the warming experiments analyzed by Rustad et al. (2001) and, more recently, by Wu et al. (2011). Our hypothesis is that the faster soil organic matter decomposition, which is driven by increased soil temperature, leads to a faster mineralization in a period in which the crop, and its rooting system, is still unable to uptake most of the nutrients that can become available in the soil. This was demonstrated in the current study given the fact that the net carbon balance $\left(\mathrm{C}_{\text {input }}-\mathrm{C}_{\text {output }}\right)$ of the crop grown on artificially warmed soil was the same as that in the control (Fig. 3). This suggests substantial homeostasis exists in the carbon balance when observed on a seasonal timescale, which finally restricts the effect of heat waves occurring during late winter/early spring mainly because of substrate limitations to respiration in the last part of the season (Kirschbaum, 2004; Eliasson et al., 2005; Knorr et al., 2005; Davidson and Jenssens, 2006; Hartley et al., 2007). However, such an effect may also be attributed to changes in microbial diversity and physiology (Allison et al., 2010), but this second hypothesis is unlikely due to the short duration of the warming effect that was considered in this study. It is worth noting that this result is of interest for other types of investigations and, in particu-

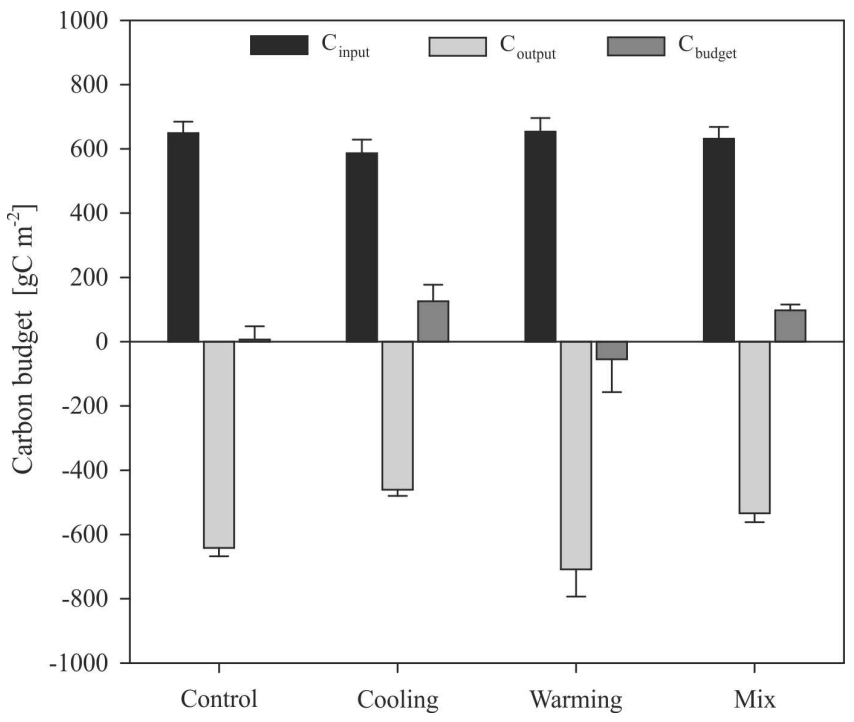

Fig. 3. Total carbon input $\left(\mathrm{C}_{\text {input }}\right)$, carbon output $\left(\mathrm{C}_{\text {output }}\right)$ and carbon budget $\left(\mathrm{C}_{\text {budget }}\right)$ of the studied agroecosystem. Negative values represent carbon losses. Vertical bars represent the standard error $(n=3)$.

lar, for ongoing studies that are trying to address the effect of changes in soil surface albedo on the carbon balance and crop productivity. For instance, the agricultural use of biochar, the dark carbonaceous residue of biomass pyrolysis, may in fact have similar effects to our soil warming treatment, as its application prior to sowing can lead to a substantial decrease in surface albedo in the period that precedes full canopy cover (Genesio et al., 2012). Our study shows that such changes in the surface energy balance do in fact alter soil temperature, cause detectable priming of soil organic matter decomposition and enhance soil $\mathrm{CO}_{2}$ efflux during late winter/early spring. However, on a seasonal timescale there is hardly any affect on the overall carbon budget of the crop, unless other effects of the amendment (i.e. increased water holding capacity or improved plant nutrition) cause an increase in crop yields.

As expected, heterotrophic respiration was slightly diminished in the soil cooling treatment, and the overall carbon savings that were made during late winter/early spring could not be compensated by higher respiration rates during the crop growing period. In fact, when the soil warmed up and its temperature became comparable to that of the control, heterotrophic respiration remained lower. The most likely interpretation for such an effect is that the large albedo-driven decrease in soil temperature that was observed in the period before complete crop cover (up to $-5.3{ }^{\circ} \mathrm{C}$ at $5 \mathrm{~cm}$ depth on DOY 131) may cause changes in the soil microbial functions, leading to reduced organic matter decomposition rates (Muhr et al., 2009). On the other hand, soil cooling also caused decreased harvest that did not affect overall carbon input. This was not due to changes in phenology, which was scarcely 

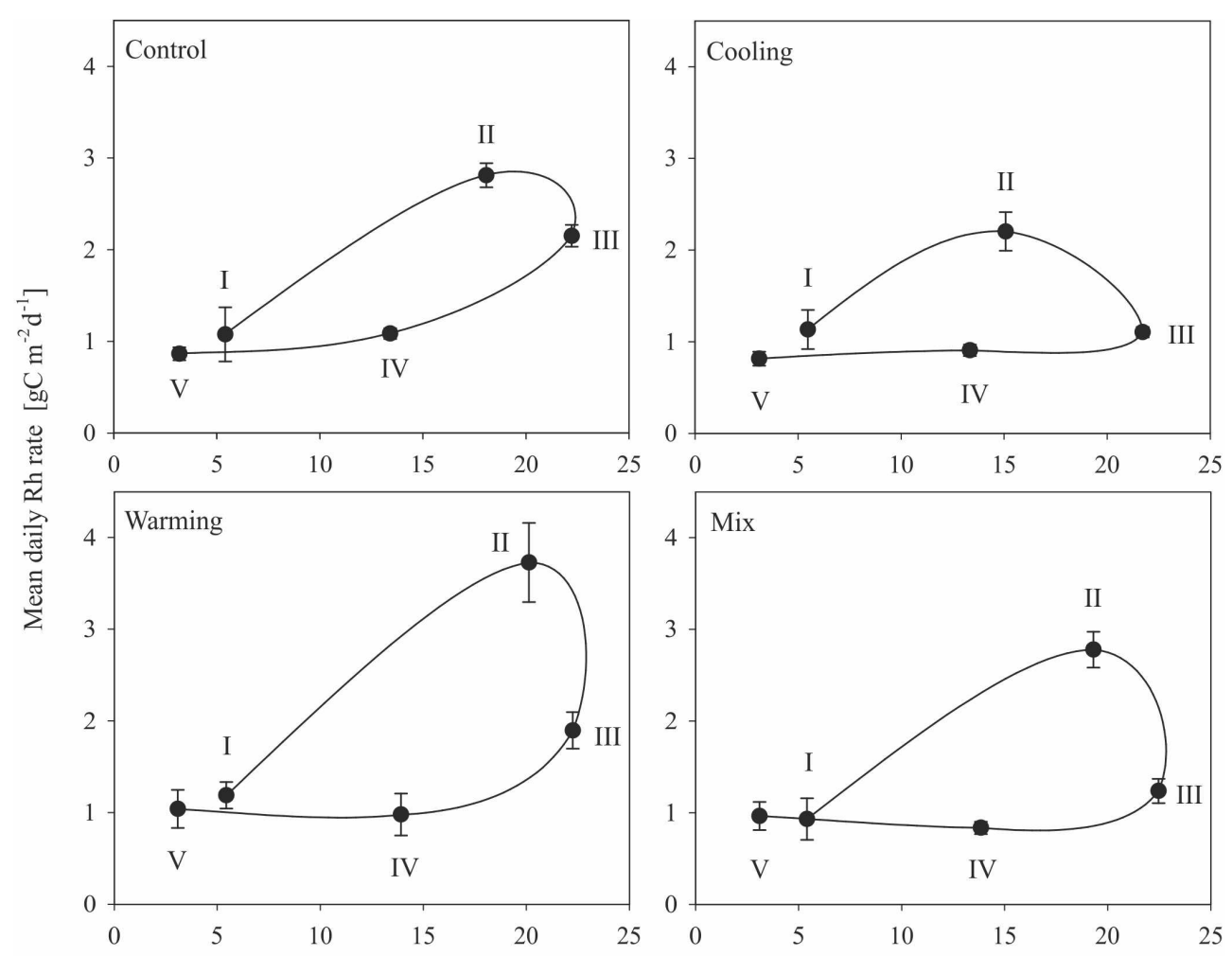

Soil temperature at $5 \mathrm{~cm}$ depth $\left[{ }^{\circ} \mathrm{C}\right]$

Fig. 4. Heterotrophic respiration rates vs. soil temperature at $5 \mathrm{~cm}$ by treatment and period (I to V). Vertical and horizontal bars represent the standard error $(n=3)$.

affected by soil cooling, but rather to a decrease in the number of germinating seeds, which led to a decrease in plant density and, possibly, a reduction in soil nutrient availability in response to lower soil organic matter (SOM) mineralization rates. The observation that cold spells may lead to reduced crop yields is not novel (Fuller et al., 2007), but the effect of extreme cold events in the late winter/early spring on carbon accumulation in soils poses some interesting considerations. Recent studies on alternative tillage practices in crop management (Licht and Al-Kaisi, 2005; Al-Kaisi et al., 2005) have already reported a decrease in soil temperature and an increase in carbon accumulation driven by no-tillage, even though they did not relate the increase in carbon storage to the decrease in soil temperature. Such an association is especially important in the light of recent climate modelling studies that support the idea of an increased likelihood of cold in Europe as a direct consequence of ice cover reduction in the Arctic (Fereday et al., 2012). The preliminary nature of our results and the large uncertainty associated with such climate predictions (based on Arctic ice melting effects) prevents excessive generalization of the idea of a complex feedback mechanism by which global warming will eventually cause ice cover reduction, translating into a higher frequency of cold winters over Europe and thus eventually leading to a net carbon sequestration in agricultural soils. But this idea certainly calls for new and more extensive field studies that can actually address the mechanisms associated with a decrease in soil temperature and the conservation of soil carbon stocks in croplands.

A final consideration examines the likely consequences of an increase in the amplitude and frequency of warming and cooling extreme events on the carbon balance of crop systems. Our study highlights that late winter/early spring heat waves are unlikely to cause depletion of soil carbon as resource supply rather than reaction kinetics appears to be the key limiting factor for heterotrophic respiration; on the other hand, substantial soil cooling occurring at the same stage in crop development may cause net carbon accumulation in soils. When combined, an increase in the frequency of both types of extreme events (Meehl and Tebaldi, 2004; Fereday et al., 2012) is therefore unlikely to have large effects on the soil carbon balance of European irrigated croplands. A conclusion that certainly warrants further investigations involving the use of validated simulation models capable of capturing short-term soil warming and cooling effects on the dynamics of soil organic matter, soil carbon fluxes and stocks, and their critical determinants. 
Acknowledgements. This research was funded by the European Commission project CARBO-Extreme (FP7/2007-2013 contract number 226701). The authors would like to thank Diego Chiabà, Alessio Dalla Torre and Matteo Danelon for help during experiment implementation and maintenance. We also thank Cristina Martinez for useful suggestions and proof corrections.

Edited by: S. Liu

\section{References}

Alberti, G., Delle Vedove, G., Zuliani, M., Peressotti, A., Castaldi, S., and Zerbi, G.: Changes in $\mathrm{CO}_{2}$ emissions after crop conversion from continuous maize to alfalfa, Agr. Ecosys. Environ., 136, 139-147, 2010.

Al-Kaisi, M. M., Yin, X., and Licht, M. A.: Soil carbon and nitrogen changes as influenced by tillage and cropping systems in some Iowa soils, Agr. Ecosys. Environ., 105, 635-647, 2005.

Allison, S. D., Wallenstein, M. D., and Bradford, M. A.: Soil-carbon response to warming dependent on microbial physiology, Nat. Geosci., 3, 336-340, 2010.

Biradar, C. M., Thenkabail, P. S., Noojipady, P., Li, Y., Dheeravath, V., Turral, H., Velpuri, M., Gumma, M. K., Gangalakunta, O. R. P., Cai, X. L., Xiao, X., Schull, M. A., Alankara, R. D., Gunasinghe, S., and Mohideen, S.: A global map of rainfed cropland areas (GMRCA) at the end of last millennium using remote sensing, Int. J. Applied Earth Obs., 11, 114-129, 2009.

Bond-Lamberty, B. and Thomson, A.: Temperature-associated increases in the global soil respiration record, Nature, 464, 579582, 2010.

Cox, P. M., Betts, R. A., Jones, C. D., Spall, S. A., and Totterdell, I. J.: Acceleration of global warming due to carbon-cycle feedbacks in a coupled climate model, Nature, 408, 184-187, 2000.

Davidson, E. A. and Janssens, I. A.: Temperature sensitivity of soil carbon decomposition and feedbacks to climate change, Nature, 440, 165-173, 2006

Davidson, E. A., Savage, K., Verchot, L. V., and Navarro, R.: Minimizing artifacts and biases in chamber-based measurements of soil respiration, Agr. Forest Meteorol., 113, 21-37, 2002.

De Boeck, H. J., Dreesen, F. E., Janssens, I. A., and Nijs, I.: Climatic characteristics of heat waves and their simulation in plant experiments, Glob. Change Biol., 16, 1992-2000, 2010.

Della Marta, P. M., Haylock, M. R., Luterbacher, J., and Wanner, H.: Doubled length of western European summer heat waves since 1880, J. Geophys. Res., 112, D15103, doi:10.1029/2007JD008510, 2007.

Delle Vedove, G., Alberti, G., Zuliani, M., Peressotti, A., Inglima, I., and Zerbi, G.: Automated Monitoring of Soil Respiration: an Improved Automatic Chamber System, Italian Journal of Agronomy, 4, 377-382, 2007.

Dungait, J. A. J., Hopkins, D. W., Gregory, A. S., and Whitmore, A. P.: Soil organic matter turnover is governed by accessibility not recalcitrance, Glob. Change Biol., 18, 1781-1796, 2012.

Easterling, D. R., Meehl, G. A., Parmesan, C., Changnon, S. A., Karl, T. R., and Mearns, L. O.: Climate Extremes: Observations, Modeling, and Impacts, Science, 289, 2068-2074, 2000.

Eliasson, P. E., McMurtrie, R. E., Pepper, D. A., Strömgren, M., Linder, S., and Ågren, G.: The response of heterotrophic $\mathrm{CO}_{2}$ flux to soil warming, Glob. Change Biol., 11, 167-181, 2005.
FAO: World reference base for soil resources 2006, FAO, Rome, 2006.

Fehr, W. R., Caviness, C. F., Burmood, D. T., and Pennington, J. S.: Stage of development descriptions for soybeans, Glycine max (L.) Merrill, Crop Sci., 11, 929-931, 1971.

Fereday, D. R., Maidens, A., Arribas, A., Scaife, A. A., and Knight, J. R.: Seasonal forecasts of northern hemisphere winter 2009/10, Environ. Res. Lett., 7, 034031, doi:10.1088/17489326/7/3/034031, 2012.

Fuller, M. P., Fuller, A. M., Kaniouras, S., Christophers, J., and Fredericks, T.: The freezing characteristics of wheat at ear emergence, Eur. J. Agron., 26, 435-441, 2007.

Genesio, L., Miglietta, F., Lugato, E., Baronti, S., Pieri, M., and Vaccari, F. P.: Surface albedo following biochar application in durum wheat, Environ. Res. Lett., 7, 014025, doi:10.1088/17489326/7/1/014025, 2012.

Granier, A., Reichstein, M., Bréda, N., Janssens, I. A., Falge, E., Ciais, P., Grünwald, T., Aubinet, M., Berbigier, P., Bernhofer, C., Buchmann, N., Facini, O., Grassi, G., Heinesch, B., Ilvesniemi, H., Keronen, P., Knohl, A., Köstner, B., Lagergren, F., Lindroth, A., Longdoz, B., Loustau, D., Mateus, J., Montagnani, L., Nys, C., Moors, E., Papale, D., Peiffer, M., Pilegaard, K., Pita, G., Pumpanen, J., Rambal, S., Rebmann, C., Rodrigues, A., Seufert, A., Seufert, G., Tenhunen, J., Vesala, T., and Wang, Q.: Evidence for soil water control on carbon and water dynamics in European forests during the extremely dry year: 2003, Agr. Forest Meteorol., 143, 123-145, 2007.

Hartley, I. P., Heinemeyer, A., and Ineson, P.: Effects of three years of soil warming and shading on the rate of soil respiration: substrate availability and not thermal acclimation mediates observed response, Glob. Change Biol., 13, 1761-1770, 2007.

Heimann, M. and Reichstein, M.: Terrestrial ecosystem carbon dynamics and climate feedbacks, Nature, 451, 289-92, 2008.

Jentsch, A. and Beierkuhnlein, C.: Research frontiers in climate change: Effects of extreme meteorological events on ecosystems, C. R. Geoscience, 340, 621-628, 2008.

Jentsch, A., Kreyling, J., and Beierkuhnlein, C.: A new generation of climate change experiments: events, not trends, Front. Ecol. Environ., 5, 315-324, 2007.

Jones, C. D., Cox, P., and Huntingford, C.: Uncertainty in climatecarbon-cycle projections associated with the sensitivity of soil respiration to temperature, Tellus B, 55, 642-648, 2003.

Karl, T. R. and Trenberth, K. E.: Modern Global Climate Change, Science, 302, 1719-1723, 2003.

Kirschbaum, M. U. F.: Soil respiration under prolonged soil warming: are rate reductions caused by acclimation or substrate loss?, Glob. Change Biol., 10, 1870-1877, 2004.

Knorr, W., Prentice, I. C., House, J. I., and Holland, E. A.: Longterm sensitivity of soil carbon turnover to warming, Nature, 433, 298-301, 2005.

Licht, M. A. and Al-Kaisi, M.: Strip-tillage effect on seedbed soil temperature and other soil physical properties, Soil Till. Res., 80, 233-249, 2005.

Lloyd, J. and Taylor, J. A.: On the temperature dependence of soil respiration, Funct. Ecol., 8, 315-323, 1994.

Loubet, B., Laville, P., Lehuger, S., Larmanou, E., Fléchard, C., Mascher, N., Genermont, S., Roche, R., Ferrara, R. M., Stella, P., Personne, E., Durand, B., Decuq, C., Flura, D., Masson, S., Fanucci, O., Rampon, J.-N., Siemens, J., Kindler, R., Gabrielle, 
B., Schrumpf, M., and Cellier, P.: Carbon, nitrogen and Greenhouse gases budgets over a four years crop rotation in northern France, Plant Soil, 343, 109-137, 2011.

Mahecha, M. D., Reichstein, M., Carvalhais, N., Lasslop, G., Lange, H., Seneviratne, S. I., Vargas, R., Ammann, C., Altaf Arain, M., Cescatti, A., Janssens, I. A., Migliavacca, M., Montagnani, L., and Richardson, A. D.: Global Convergence in the Temperature Sensitivity of Respiration at Ecosystem Level, Science, 329, 838-840, 2010.

Meehl, G. A. and Tebaldi, C.: More Intense, More Frequent, and Longer Lasting Heat Waves in the 21st Century, Science, 305, 994-997, 2004.

Meehl, G. A., Karl, T., Easterling, D. R., Changnon, S., Pielke Jr., R., Changnon, D., Evans, J., Groisman, P. Y., Knutson, T. R., Kunkel, K. E., Mearns, L. O., Parmesan, C., Pulwarty, R., Root, T., Sylves, R. T., Whetton, P., and Zwiersl, F.: An Introduction to Trends in Extreme Weather and Climate Events: Observations, Socioeconomic Impacts, Terrestrial Ecological Impacts, and Model Projections, B. Am. Soc. Meteorol., 81, 413-416, 2000.

Menzel, A., Sparks, T. H., Estrella, N., Koch, E., Aasa, A., Ahas, R., Alm-Kübler, K., Bissolli, P., Braslavská, O., Briede, A., Chmielewski, F. M., Crepinsek, Z., Curnel, Y., Dahl, Å, Defila, C., Donnelly, A., Filella, Y., Jatczak, K., Måge, F., Mestre, A., Nordli, Ø., Peñuelas, J., Pirinen, P., Remišová, V., Scheifinger, H., Striz, M., Susnik, A., Van Vliet, A. J. H., Wielgolaski, F.-E., Zach, S., and Zust, A.: European phenological response to climate change matches the warming pattern, Glob. Change Biol., 12, 1969-1976, 2006.
Muhr, J., Borken, W., and Matzner, E.: Effects of soil frost on soil respiration and its radiocarbon signature in a Norway spruce forest soil, Glob. Change Biol., 15, 782-793, 2009.

Pavelka, M., Acosta, M., Marek, M. V., Kutsch, W., and Janous, D.: Dependence of the $\mathrm{Q}_{10}$ values on the depth of the soil temperature measuring point, Plant Soil, 292, 171-179, 2007.

Rustad, L. E., Campbell, J. L., Marion, G. M., Norby, R. J., Mitchell, M. J., Hartley, A. E., Cornelissen, J. H. C., Gurevitch, J., and GTCE-NEWS: A meta-analysis of the response of soil respiration, net nitrogen mineralization, and aboveground plant growth to experimental ecosystem warming, Oecologia, 126, 543-562, 2001.

Setiyono, T. D., Cassman, K. G., Specht, J. E., Dobermann, A., Weiss, A., Yang, H., Conley, S. P., Robinson, A. P., Pedersen, P., and De Bruin, J. L.: Simulation of soybean growth and yield in near-optimal growth conditions, Field Crops Res., 119, 161-174, 2010.

Wu, Z., Dijkstra, P., Koch, G. W., Peñuelas, J., and Hungate, B. A.: Responses of terrestrial ecosystems to temperature and precipitation change: a meta-analysis of experimental manipulation, Glob. Change Biol., 17, 927-942, 2011. 